\title{
HEAT Repeat-Containing Protein 3
}

National Cancer Institute

\section{Source}

National Cancer Institute. HEAT Repeat-Containing Protein 3. NCI Thesaurus. Code C134621.

HEAT repeat-containing protein $3(680 \mathrm{aa}, \sim 75 \mathrm{kDa})$ is encoded by the human HEATR3 gene. This protein is involved in nuclear import of RNAs and RNA-binding proteins. 